\title{
Obituary
}

\section{LESLIE THOMAS MORTON}

1907-2004

Leslie Morton, who died on 17 February at the age of ninety-six, had a distinguished career as a medical librarian, but was known to the world of medical history and bibliography as compiler of the indispensable reference work 'Garrison-Morton'.

He started in the Medical Sciences Library at UCL in 1923, attending the UCL library school parttime, moved to the Royal Society of Medicine in 1933, and in 1935 became Librarian of St Thomas's Hospital Medical School. Following posts with the British Council Medical Department (1944-46) and British Medical Journal (1947-59) he was Librarian of the National Institute of Medical Research at Mill Hill until 1972. After retirement he was libraries adviser to the British Postgraduate Medical Federation. His work was honoured by the (British) Library Association's Medical Section, which he helped to found, and by the (American) Medical Library Association.

Several of his friends spent time as juniors at the Wellcome Library. Leslie turned down a post there in 1930, but was one of the Library's first users when his friend William Bishop, later founding-editor of this journal, became Librarian in 1946.

Leslie produced numerous books and articles on medical librarianship, bibliography and history. His first book, How to use a medical library, appeared a lifetime ago, in 1934. Among his historical publications were A bibliography of medical and biomedical bibliography $(1989,1992)$ and $A$ chronology of medicine and related sciences (1997) (both with Robert Moore); visits to the Wellcome Library to keep them up to date continued to the end of his life.

His magnum opus, however, was 'Garrison-Morton'. In 1938 he conceived the idea of a bibliography of the significant texts in the history of medicine, and took as his base the 'Revised students' checklist' compiled by Fielding Garrison (1870-1935). When St Thomas's Library was evacuated to Guildford, Leslie took his shoeboxes of slips with him to work on in the evenings, when there was little else to do, and on Saturday visits to London. The book appeared in 1943, entitled A medical bibliography: a check-list of texts illustrating the history of the medical sciences, with Garrison's name generously placed first on the title page, and became the indispensable tool of librarians, students, historians, historically-minded doctors, book collectors and dealers. Garrison-Morton numbers came to be cited as a canon, although some dealers mysteriously seem to regard "not in GarrisonMorton" as a selling point!

Leslie produced, single-handed, three much enlarged editions up to 1983. The 5th edition (1989), edited by Jeremy Norman, at last gave him full credit with the title Morton's medical bibliography. He was aware that his arrangement and selection were not perfect, but felt that his generalist's perspective was preferable to the more subjective viewpoint of specialists in particular subjects.

He had a happy family life in Pinner with his wife Bertha, children and grandchildren, and was a keen traveller. He and Bertha celebrated their diamond wedding in 1993, four years before her death. When her health began to fail, he mastered domestic skills, remaining self-sufficient to the end. He was the kindest and most unassuming of men, always with a twinkle in his eye, and never lost sight of the principle that libraries, librarians and bibliographies exist to serve their users. His energy seemed inexhaustible and he was a friend to generations of younger colleagues. Our sympathy goes to his family.

John Symons 